\section{Opportunities And Consequences Of Spending Money In The Cotton Industry During The Soviet Era}

\section{Yakubova Dilaram Tajievna}

Teacher Of Denau Institute Of Entrepreneurship And Pedagogy, Uzbekistan

\author{
G OPEN ACCESS \\ The American Journal \\ of Applied Sciences \\ JULY 2020 \\ Page No.: 55-59 \\ Volume-II Issue-VII \\ PUBLISHED: 30 JULY 2020 \\ www.usajournalshub.com/inde \\ x.php/tajas \\ Copyright: Original content \\ from this work may be used \\ under the terms of the \\ Creative Commons Attribution \\ 4.0 licence.
}

\begin{abstract}
The article reflects the scientific policy of the Soviet government in Uzbekistan, the unilateral policy of cotton monopoly, the causes and consequences of the reduction of other crops in agriculture, the results of testing new types of agricultural machinery in the development of cotton.
\end{abstract}

Keywords: soviet, cotton, labor, kolkhoz, money-material, material reserves, sovkhoz, agrotechnics, irrigation-amelioration, culture. cyanamide-calcium, horizontal spiidelli.

\title{
Introduction
}

The main goal of the Soviet agrarian policy in Uzbekistan was to reduce the number of melons and gourds, livestock, silk and other industries in order to increase the productivity of cotton crops. To this end, on the one hand, efforts were made to increase the yield of cotton at the expense of the centner, and on the other hand, to reduce as much as possible the labor costs of labor and money, to reduce production costs per quintal.As a result, the share of collective farm income distributed in working days will increase, and the Soviet state put on the agenda important measures to increase the material interests of collective farmers and improve their living standards. In fact, this 
policy was implemented only on paper, due to the level of mechanization of agricultural work and the introduction of new methods of agricultural technology at the expense of labor and monetary costs for the collective farms of the republic to grow one quintal of cotton. In practice, until 1955, the collective farms spent on the maintenance of each hectare and the cultivation of cotton quintals. The exact amount of money and material spent on labor was not recorded.

The analysis of production costs of collective farms in Surkhandarya region showed that most collective farms did not take full advantage of opportunities to increase cotton yields and reduce production costs, as well as did not pay enough attention to the proper use of machinery, labor, money and materials.

When the amount of money and materials spent on cotton growing on the Lenin, Kirov and Stalin collective farms in the Sherabad district of Surkhandarya region was carefully examined, the money and material expenditures of all three collective farms were still high.It was found that there is a possibility of a significant reduction and thus a significant reduction in the cost of cotton production. In 1955 the following amounts of money and materials were spent on the maintenance of one hectare of cotton and the cultivation of 1 quintal of cotton in these collective farms. and 90.7 soums, in Stalin's collective farms 1525 and 84.6 soums. Expenditures not directly related to cotton growing were 442 soums per hectare and 15.2 soums per centner at the Lenin collective farm, 347 and 13.8 soums at the Kirov collective farm, and 284.1 and 15.7 soums at the Stalin collective farm.Since the Kirov kolkhoz produced less than the Lenin kolkhoz, one quintal of cotton cost more cotton and 104.5 soums. In the kolkhoz "Communism", which produced the least (18 quintals per hectare), the cost per hectare was less than in the two kolkhozes (1809.1 soums), but one quintal of cotton cost more money and materials (100.3 soums). which, shows that the Lenin and Kirov kolkhozes were careless in saving money and material reserves. As a result of this negligence, money and materials are wasted and the cost of the product increases.In these three kolkhozes, a great deal of money was spent on paying MTS in kind, on purchasing mineral fertilizers, and on paying for the labor of those who were engaged in the cotton harvest from abroad. Also, in accordance with the Constitution of the Uzbek SSR since 1959 on the basis of the law on the introduction and development of crop rotation in collective and state farms of Surkhandarya region, land and water in the republic are state property. The land and water given to the collective and state farms for use were used to strengthen and develop the socialist economic system, increase public wealth, and steadily increase the material well-being and cultural level of the workers.Crop rotation, which is an important part of the scientifically based system of agricultural work, was taken as the basis for the production activities of collective and state farms. 
Collective farms and state farms used land, which was the main means of agricultural production, in a purposeful and economical manner. For this purpose the kolkhozes and sovkhozes carried out the following work:

- As a result of a systematic increase in crop yields in agricultural production and the development of new lands;

- a set of agro-technical and irrigation and reclamation measures

As a result of application and application of advanced experience and scientific achievements in production, the yield of cotton, alfalfa, corn and other agricultural crops has increased, and the productivity of orchards, vineyards, hayfields and pastures has increased; - protection and maintenance of planted trees for land reclamation, soil conservation, field protection and water conservation, expansion of tree planting areas and landscaping of settlements; - The necessary measures to combat weeds, pests and diseases of agricultural crops have been resolutely implemented. The Supreme Soviet of the Soviet Socialist Republic of Uzbekistan has taken the most important measures in the field of introduction of crop rotation in all collective and state farms - further development of agriculture, especially cotton growing, raising the culture of farming.Lenin, however, in recent years the republic, the local soviet and agricultural bodies, many kolkhozes and sovkhozes, have been neglecting the question of mastering crop rotation without any justification. In the development of cotton-growing the main attention was paid to the expansion of cotton fields, cotton and other agricultural crops, which were the main task of socialist agriculture.Insufficient attention was paid to increasing yields. This situation also hindered the development of animal husbandry. In 1959, as a result of mechanization of the cotton harvest, the collective and state farms of the republic harvested 330,000 tons of cotton by machine. In 1959, 6,800 harvesting machines worked in the collective and state farms of the republic. On average, each machine picked 48.5 tons of cotton. Timely and high-quality shedding of cotton leaves is of great importance for successful machine harvesting. Experiments in 1955-1959 showed that the best results were obtained by treating cotton with cyanamide-calcium at a daily temperature of 17 degrees and above.Calcium-cyanamide with silica sodium fluoride was used to shed leaves in the main areas. magnesium chlorate was used in areas where dew does not fall, or where treatment is carried out in the evening.In Surkhandarya oasis, during the study of data on the first cotton picking by machines in 1959, before the start of the machine harvest, the total area allocated for harvesting was determined. Preparation of turning areas for harvesting machines with a width of -6 meters is organized.According to the sources, in 1959-1960, in Surkhandarya region, when at least $60 \%$ of the cotton-picking bins were opened by machine, cotton was harvested by machine with a horizontal spindle. was launched when 65-70 percent of the cobs were opened for harvesting. Experience in cotton growing during the Soviet era of the 1960s showed that when cotton was harvested 
by machine in low-lying fields, the stalks were shed more and the cotton was harvested less.

In order to increase the productivity and quality of the machine, it was important to correctly map its penetration into the field.

During the scientific analysis of the sources on the subject, it was found that new technical parts were also tested during the cotton picking process. As a result of observations of Haydarov, a researcher at TIIIMSX, recorded in the historical data, the most productive maps for SXM-48, XVS-1,2 and SXS-1,2 were identified. The document states that the area of the machine picker is divided into zones facing the transverse, and the minimum width of the most time-consuming part of the machine for turning is defined as follows. For the SXM-48M machine-32 rows XVS-1,2, 52, SXS-1,2, 20 SXM-48, SXM-48M and XVS-1,2 machines fell to the right side of the machine and picked cotton in a combined way. It was determined that when the XVS-1,2 enters the car, one of the front wheels or one of the steering wheels must pass between the adjacent rows. It is known that the bunker of the XVS-1,2 machine is loaded with cotton: directly transported, according to which the method of picking cotton and transporting the crop without bales was first introduced at the site of the XVS-1.2 machine.In 1961, Uzbek cotton growers produced 3,200,000 tons of cotton, 600,000 tons of vegetables, 360,000 tons of potatoes, 600,000 tons of melons, 312,000 tons of fruits and grapes; from livestock products: 155 thousand tons of meat, 315 thousand tons of milk, 84 million eggs, 22 thousand tons of wool, 100 thousand pieces of astrakhan leather. In the third year of the seven-year plan, 1.5 million hectares of land were planted with square-seeded seedlings, including a certain amount of seeds planted on 250,000 hectares. One million 200 thousand hectares of cotton are mainly cultivated without ketmon. Corn and white oats are planted in 190,000 hectares. at least 600,000 tons of cotton were harvested by machine.In conclusion, the Soviet government's policy of cotton monopoly in the region was aimed at satisfying the Center's demand for raw cotton and increasing the productivity of cotton in agricultural mechanization.

\section{REFERENCES}

1. State archive of Surkhandarya region. Fund-48, opisSurkhandarya VDA, 19 funds, list 1 , case 45 , sheet 6 .

2.M.S.Istomin. High-yield agro-techniques from fine-fiber cotton in Surkhandarya. T., Publishing House of the Central Committee of the Communist Party of Uzbekistan, 1969. Pages 5-6.

3. Archive of Surkhandarya regional khokimiyat branch of UzPA, fund 1, list 5, case 46, page 60.

4. State archive of Surkhandarya region. Fund-48, opisSurkhandarya VDA, 19 funds, list 1 , case 48, page 19. 
5.M.S.Istomin. High-yield agro-techniques from fine-fiber cotton in Surkhandarya. T., Publishing House of the Central Committee of the Communist Party of Uzbekistan, 1969. Page 8 MS Istomin. High-yield agro-techniques from fine-fiber cotton in Surkhandarya. T., Publishing House of the Central Committee of the Communist Party of Uzbekistan, 1969. p.

6. Surkhandarya VDA, 18 funds, 1 list, 141 cases, 15 pages.

7.M.S.Istomin. High-yield agro-techniques from fine-fiber cotton in Surkhandarya. T., Publishing House of the Central Committee of the Communist Party of Uzbekistan, 1969. M.S.Istomin. High-yield agro-techniques from fine-fiber cotton in Surkhandarya. T., Publishing House of the Central Committee of the Communist Party of Uzbekistan, 1969.P.13.

8. Surkhandarya VDA, 18 funds, list 1 , case 147, page 27. 